\title{
Focal KATP-Associated Hyperinsulinism
}

National Cancer Institute

\section{Source}

National Cancer Institute. Focal KATP-Associated Hyperinsulinism. NCI Thesaurus. Code C131830.

KATP-associated hyperinsulinism in which there is an area of adenomatous beta-cell hyperplasia. This condition results from paternal recessive mutation(s) in either the $\mathrm{ABCC} 8$ or the KCNJ11 gene and paternal uniparental isodisomy of chromosome region $11 \mathrm{p} 15$ with loss of tumor suppressor genes expressed from the maternally inherited chromosome. 